\title{
DUKUNGAN INFORMASIONAL ORANG TUA: PENENTU KEBERHASILAN PRESTASI AKADEMIK ANAK DI PERDESAAN
}

\author{
Adelia Ratih Indrawati, Alfiasari* \\ Departemen IImu Keluarga dan Konsumen, Fakultas Ekologi Manusia, Institut Pertanian Bogor, Kampus \\ Dramaga, Bogor 16680, Indonesia \\ *)Email : alfiasari@apps.ipb.ac.id
}

\begin{abstract}
Abstrak
Pencapaian prestasi akademik anak dapat dipengaruhi oleh faktor internal dan eksternal. Faktor eksternal diantaranya adalah lingkungan keluarga, teman, dan sekolah yang berinteraksi dengan anak. Penelitian ini bertujuan untuk menganalisis dukungan sosial yang diterima anak dari lingkungannya dan juga peran kelekatan ibu-anak terhadap pencapaian prestasi akademik anak SD di perdesaan. Partisipan adalah 100 anak usia sekolah dasar yang mempunyai orang tua lengkap di wilayah perdesaan dari dua SD terpilih di lokasi penelitian. Metode pemilihan contoh menggunakan teknik acak proporsional berdasarkan jumlah siswa dan jenis kelamin anak di masing-masing sekolah terpilih. Penelitian menemukan bahwa dukungan informasional dari orang tua yang semakin baik berhubungan nyata dengan semakin baiknya prestasi akademik anak. Selain itu juga ditemukan bahwa kelekatan ibu-anak yang semakin baik berhubungan nyata dengan prestasi akademik anak usia sekolah dasar di perdesaan. Hanya saja, uji regresi terhadap model yang diduga, menunjukkan bahwa hanya dukungan informasional dari orang tua yang lebih memberikan pengaruh yang nyata terhadap peningkatan prestasi akademik anak dibandingkan variabel lain dalam penelitian.
\end{abstract}

Kata kunci: anak usia sekolah, dukungan sosial, kelekatan emosi, keluarga perdesaan, prestasi akademik

\section{Parental Informational Support: the Determinant Factor of Academic Achievement Among School-Age Children in Rural Areas}

\begin{abstract}
Academic achievement can be influenced by internal and external factors. External factors are including family, friend, and school environment that interact with children. This study aimed to analyze the social support received by children from the environment and also to analyze the role of the mother-child attachment to the academic achievement of elementary school children in rural areas. Participants were 100 primary school-age children who live in intact families in rural areas from the two selected primary schools in the study sites. The sampling technique was using proportional random sampling; based on the number and sex of the students in each selected schools. The study found that the better informational support of the parents, the better academic achievement of children. It is also found that the better mother-child attachment, the better academic achievement of primary school-age children in rural areas. However, regression test of the hyphothesis model, this study showed that only the informational support of the parent is the most significant determinant factor on the academic achievement of children in rural areas than the other variables.
\end{abstract}

Keywords: school-age children, social support, attachment, rural family, academic achievement

\section{PENDAHULUAN}

Masyarakat perdesaan memiliki berbagai macam keterbatasan dalam meningkatkan kualitas hidupnya. Tingkat pendapatan dan pendidikan masyarakat di perdesaan yang rendah seringkali mengakibatkan keluarga di perdesaan sulit untuk memaksimalkan kualitas hidupnya. Hal ini juga yang menyebabkan mereka cenderung lebih banyak mengalokasikan waktunya pada kegiatan usaha tani atau dagang untuk meningkatkan pendapatan sehingga kurang untuk melakukan tugas dan fungsi-fungsi keluarga lainnya (Surung \& Dahlan, 2012). Keterbatasan waktu yang dimiliki dalam berinteraksi dengan anak karena harus memenuhi kebutuhan ekonomi keluarga dan juga pengetahuan yang rendah tentang pengasuhan akibat tingkat pendidikan yang juga rendah, tentu saja menjadi permasalahan yang dihadapi keluarga di perdesaan untuk dapat mengoptimalkan pengasuhan untuk anak-anaknya.

Anak akan mengalami masa pertumbuhan maupun perkembangan sesuai dengan 
usianya, dari tahap pranatal sampai remaja. Pada masa sekolah (school-age) adalah sebuah tahapan perkembangan psikososial yang dikenal sebagai tahap industry-inferiority menurut Erikson (Santrock, 2007). Pada masa sekolah ini, anak sangat aktif mempelajari apa saja yang ada di lingkungannya. Selain berada pada tahapan industry-inferiority seperti yang dikatakan Erik Erikson, pada periode ini anak juga masuk dalam tahap perkembangan laten menurut Sigmund Freud (Santrock, 2007). Pada tahap ini, kepuasan anak didorong oleh rasa ingin tahu yang tinggi atas hal-hal yang terjadi di sekitarnya sehingga mereka dapat mengeksplorasi apa yang dialaminya. Oleh karenanya, lingkungan keluarga dan sekolah yang membuat anak memperoleh kemampuan berimajinasi dalam mengkoordinasi pemikirannya sangat dibutuhkan anak.

Rasa ingin tahu yang besar dan juga keaktifan anak usia sekolah untuk mempelajari segala hal di lingkungannya merupakan faktor pendorong anak untuk berprestasi. Pencapaian prestasi anak akan baik jika anak memiliki motivasi berprestasi yang baik pula (Tiwari et al., 2014). Prestasi belajar menggambarkan penguasaan siswa terhadap materi pelajaran yang diberikan. Untuk mengetahui seberapa jauh pengalaman belajar siswa yang telah dipahami siswa maka dilakukan evaluasi belajar (Akbar \& Hawadi, 2001). Adapun faktor yang memengaruhi prestasi belajar dapat berasal dari diri sendiri (faktor internal) dan dari luar dirinya (faktor eksternal). Faktor internal meliputi kemampuan intelektual, minat, bakat, sikap, motivasi berprestasi, konsep diri, dan sistem nilai. Sementara itu, pada faktor eksternal dapat mencakup lingkungan sekolah, lingkungan keluarga, dan lingkungan masyarakat (Akbar \& Hawadi, 2001).

Teori Bronfenbrenner menjelaskan lingkungan anak terdiri dari lingkungan mikro, salah satunya keluarga dan lingkungan meso yang mencakup hubungan antara keluarga dengan teman, sekolah, dan tetangga (Puspitawati, 2012). Lingkungan keluarga merupakan lingkungan terdekat anak yang tentu saja dukungan yang diberikan keluarga untuk mencapai prestasi setinggi-tingginya menjadi faktor penting yang mendorong anak untuk mencapai prestasi akademik yang terbaik. Selain itu, dukungan dari lingkungan sekolah dan pertemanan juga berperan penting dalam perkembangan anak. Pada proses perkembangannya, anak akan membutuhkan dukungan sosial dalam proses adaptasinya (Wandansari, 2004). Dukungan sosial yang tidak memadai yang diberikan dari orang tua kepada anak akan memengaruhi ketidaknyamanan anak dalam sekolah, misalnya dalam mengerjakan tugas anak belum percaya diri terhadap hasil yang dikerjakan (Cutrona et al., 1994). Dukungan sosial yang diberikan kepada anak usia sekolah dasar dapat berupa dukungan emosional, instrumental, dan informasi (Gordon, 2011).

Ketiga bentuk dukungan sosial untuk anak menurut Gordon (2011) merujuk pada bantuan yang diberikan kepada anak dalam bentuk kasih sayang, pemberian materi, dorongan atau nasehat, dan bantuan dalam memecahkan masalah yang bersumber dari orang tua, guru, dan teman. Dukungan emosional merupakan bantuan yang diterima anak dalam bentuk kasih sayang dan cinta yang dirasakan anak dari orang tua, guru, dan teman. Sementara itu, dukungan instrumental adalah bantuan yang diterima anak dalam bentuk penyediaan barang dan jasa (uang) dari orang tua, guru, dan teman. Dukungan informasional dapat berupa bantuan yang diterima anak dalam bentuk penyediaan informasi atau saran dari orang tua, guru, dan teman (Gordon, 2011).

Selain dukungan dari lingkungan, khususnya dukungan dari orang tua, keluarga yang memberi pengasuhan dengan praktek kelekatan (attachment) yang baik akan memberikan rasa aman pada anak sehingga anak memiliki motivasi yang baik dalam mencapai tahap perkembangannya (Miller \& Commons, 2010). Bowlby (1973) diacu dalam Lamont (2010) mendefinisikan kelekatan emosi sebagai hubungan emosional atau hubungan yang bersifat afektif antara dua orang yang memiliki arti khusus, seperti pada ikatan ibu dan anak. Kedekatan yang dibangun ini akan bertahan cukup lama dan memberikan rasa aman walaupun figur lekat tidak di hadapan anak. Hubungan ini memberikan kesempatan bagi anak untuk mengeksplorasi lingkungan maupun kehidupan sosial sehingga hubungan ini dapat mengurangi perilaku antisosial (Yaacob et al., 2015).

Anak pada tahap usia sekolah akan menunjukkan identitas dirinya, anak akan merasa bebas dari orang tuanya dan anak akan meningkatkan hubungan dengan temannya dalam hal sosial, emosi, serta pengembangan akademik (Conture \& Guitar 1993 diacu dalam Lau et al., 2012). Tuntutan perkembangan ini akan meningkatkan harapan anak untuk semakin dewasa dalam 
berkompetensi komunikatif dan akademik. Oleh karena itu, hubungan antara orang tua dan anak memiliki peran penting dalam memfasilitasi anak untuk melakukan kompetensi sosial, mengatasi masalah anak dengan strategi, dan meningkatkan orientasi motivasi (Bukatko \& Daehler, 2004 diacu dalam Lau et al., 2012). Penelitian Miller \& Commons (2010) menjelaskan kelekatan emosi yang dibangun antara orang tua dan anak akan membuat anak mampu mengatur emosinya seperti rasa takut, gelisah, dan marah serta anak memiliki perkembangan mental dan fisik yang sehat.

Pada penelitian yang dilakukan oleh Cutrona et al. (1994) dan Chen (2015), anak usia sekolah yang memiliki kelekatan emosi dan dukungan sosial yang baik dari keluarga atau lingkungannya, seperti hubungan interaksi yang baik antara orang tua dengan anak, akan meningkatkan pencapaian prestasinya. Meskipun penelitian tersebut menemukan pengaruhnya melalui variabel mediator yaitu self-efficacy, tetapi ditemukan adanya hubungan antara kelekatan emosi dengan prestasi akademik (Chen 2015) dan hubungan antara dukungan sosial yang dibangun dengan meningkatnya nilai indeks prestasi kumulatif siswa (Cutrona et al. 1994). Melalui penelitian ini, diharapkan akan memberikan jawaban terkait pengaruh langsung variabel dukungan sosial dan kelekatan emosi ibu-anak terhadap prestasi akademik anak, khususnya anak usia sekolah di daerah perdesaan. Cutrona et al. (1994) dan Chen (2015) yang mengonstruksi pengaruh kedua variabel tersebut secara tidak langsung terhadap prestasi akademik. Oleh karenanya, penelitian ini bertujuan untuk menganalisis pengaruh langsung dukungan sosial yang diterima anak dari lingkungannya dan kelekatan emosi ibu-anak terhadap prestasi akademik anak usia sekolah di wilayah perdesaan.

\section{METODE}

Penelitian ini menggunakan desain cross sectional study dengan metode pengumpulan data melalui wawancara dengan responden. Penelitian dilakukan di Desa Ciasihan dan Desa Ciasmara, Kecamatan Pamijahan, Kabupaten Bogor yang ditentukan secara purposive sebagai representasi wilayah perdesaan. Penelitian ini merupakan bagian dari penelitian Hibah Kompetensi Direktorat Pendidikan Tinggi Tahun 2015 dengan judul "Model Pendidikan Karakter pada Keluarga Perdesaan melalui Family School Partnership" yang dilakukan oleh Hastuti \& Alfiasari (2015).
Pengambilan data dilakukan pada Bulan Mei 2015.

Kerangka contoh dalam penelitian ini berjumlah 357 siswa yang merupakan jumlah siswa total kelas 4 dan 5 di kedua SD terpilih. Responden penelitian adalah 100 anak dari kerangka contoh dengan syarat tinggal bersama keluarga lengkap. Teknik pemilihan contoh menggunakan teknik acak proporsional. Teknik acak proporsional dilakukan berdasarkan jumlah siswa di masing-masing sekolah dan didasarkan pada jumlah siswa berdasarkan jenis kelamin.

Data penelitian yang dikumpulkan dalam penelitian ini berupa data primer dan data sekunder. Data primer yang dikumpulkan terdiri dari karakteristik anak, karakteristik keluarga, dan kelekatan emosi. Data sekunder berupa data rapor anak selama satu semester terakhir ketika penelitian dilakukan sebagai parameter untuk variabel prestasi akademik anak. Data primer diperoleh dari hasil wawancara dengan menggunakan instrumen terstruktur.

Kuesioner dukungan sosial yang digunakan dalam penelitian ini dikembangkan oleh Gordon (2011) yang disebut dengan Social Support Questionnaire for Children (SSQC). Dimensi dukungan sosial meliputi dukungan emosional, instrumental, dan informasional dengan jumlah pernyataan awal adalah 30 butir pernyataan. Sumber dukungan sosial yang diukur untuk ketiga dimensi adalah bersumber dari orang tua, teman, dan guru. Dukungan sosial diukur menggunakan empat skala Likert, yaitu "1=tidak pernah"; "2=kadang-kadang"; "3=sering"; dan "4=selalu". Jumlah pertanyaan dari instrumen yang digunakan dalam pengolahan data adalah 28 dengan mempertimbangkan memilih pernyataan-pernyataan yang membuat instrumen reliabel dan valid. Nilai reliabilitas untuk instrumen dukungan sosial dalam penelitian ini adalah 0,849.

Sementara itu, variabel kelekatan emosi mengacu pada Lamont (2010) yang mengukur kelekatan emosi dengan instrumen Attachment Q-Sort Questionnaire (AQSQ). AQSQ merupakan instrumen yang digunakan untuk menggambarkan hubungan kelekatan antara anak dengan pengasuh utama atau ibu. AQSQ yang digunakan dalam penelitian ini dimodifikasi oleh Alfiasari et al. (2013) yang berisi 16 pernyataan. Hanya saja dalam penelitian ini dengan mempertimbangkan aspek validitas internal maka hanya 
menggunakan 11 pernyataan yang digunakan. Kelekatan emosi diukur menggunakan tiga skala yaitu " $1=$ tidak menggambarkan hubungan saya dengan lbu saya"; "2=menggambarkan hubungan saya dengan lbu saya"; dan "3=sangat menggambarkan hubungan saya dengan Ibu saya". Nilai Cronbach's alpha variabel ini yaitu sebesar 0,533 .

Data mentah untuk variabel dukungan sosial dan kelekatan emosi selanjutnya diolah dalam bentuk indeks 0,0-100,0. Selanjutnya, variabel dukungan sosial dan kelakatan emosi dikategorikan berdasarkan cut-off point, yaitu rendah: 0,0-60,0; cukup baik: 60,0-80,0; baik: 80,0-100,0 merujuk pada cut-off point yang digunakan Khomsan (2002). Data dianalisis secara deskriptif (rata-rata, standar deviasi, nilai minimum, dan nilai maksimum) dan inferensia (korelasi dan regresi linier berganda) untuk menjawab tujuan penelitian. Analisis data menggunakan program Microsoft Office Excel dan Statistical Package for Social Science (SPSS).

\section{HASIL}

\section{Karateristik Anak dan Keluarga}

Pada penelitian ini, responden anak yang terlibat terdiri dari 55 orang anak laki-laki dan 45 orang anak perempuan dengan rata-rata usia anak yaitu 11,00 tahun. Sementara itu, berdasarkan karakteristik keluarga, hasil penelitian menemukan bahwa rata-rata usia ayah adalah 44,03 tahun, dengan umur termuda adalah 27,0 tahun dan tertua adalah 80,0 tahun. Sementara itu, rata-rata usia ibu adalah 38,19 tahun dengan umur termuda adalah 23,0 tahun dan tertua adalah 75,0 tahun. Rata-rata lama pendidikan ayah lebih tinggi jika dibandingkan rata-rata lama pendidikan ibu. Rata-rata ayah pada penelitian ini telah menamatkan SD namun tidak sampai kelas 1 SMP sedangkan rata-rata ibu tidak menamatkan jenjang sekolah dasar.

Hasil penelitian juga menemukan bahwa sebagian besar ayah mempunyai pekerjaan sebagai wirausaha atau dagang $(36,0 \%)$ dan kurang dari tiga perempat ibu $(74,0 \%)$ yaitu tidak bekerja. Tabel 1 menunjukkan rata-rata pendapatan per kapita keluarga yaitu Rp359.000,00 per bulan, dengan pendapatan terkecil Rp37.500 dan terbesar Rp4.385.714. Adapun rata-rata besar keluarga pada penelitian ini berada pada kategori keluarga sedang (5-7 orang). Secara detail, data karakteristik keluarga tersaji pada Tabel 1 .
Tabel 1 Nilai minimum, maksimum, rata-rata, dan standar deviasi variabel karakteristik keluarga keluarga

\begin{tabular}{|c|c|c|c|}
\hline $\begin{array}{l}\text { Karakteristik } \\
\text { keluarga }\end{array}$ & $\operatorname{Min}$ & Maks & Rataan $\pm S D$ \\
\hline $\begin{array}{l}\text { Usia ayah } \\
\text { (tahun) }\end{array}$ & 27,0 & 80,0 & $44,03 \pm 9,36$ \\
\hline $\begin{array}{l}\text { Usia ibu } \\
\text { (tahun) }\end{array}$ & 23,0 & 75,0 & $38,19 \pm 8,35$ \\
\hline $\begin{array}{l}\text { Lama } \\
\text { pendidikan } \\
\text { ayah (tahun) }\end{array}$ & 0,0 & 16,0 & $6,12 \pm 2,68$ \\
\hline $\begin{array}{l}\text { Lama } \\
\text { pendidikan ibu } \\
\text { (tahun) }\end{array}$ & 0,0 & 16,0 & $5,79 \pm 2,21$ \\
\hline $\begin{array}{l}\text { Pendapatan } \\
\text { per kapita } \\
\text { (Rp/bulan) }\end{array}$ & 37.500 & 4.285 .714 & $\begin{array}{c}359.000 \pm \\
458.000\end{array}$ \\
\hline $\begin{array}{l}\text { Jumlah } \\
\text { anggota } \\
\text { keluarga } \\
\text { (orang) }\end{array}$ & 3,0 & 10,0 & $5,27 \pm 1,42$ \\
\hline
\end{tabular}

\section{Dukungan Sosial}

Hasil penelitian yang tersaji pada Tabel 2 menunjukkan bahwa rata-rata indeks dukungan sosial secara keseluruhan dari seluruh sumber dukungan dan seluruh dimensi dukungan yang dirasakan anak yaitu sebesar 64,69 dengan nilai minimum sebesar 27,00 dan nilai maksimum 96,00. Artinya, dukungan sosial cukup dirasakan oleh anak dalam bentuk kasih sayang, pemberian materi, dan nasehat dari orang tua, guru, dan teman. Berdasarkan dimensi dukungan sosial, hasil penelitian menunjukkan rata-rata setiap dimensi dukungan sosial yang dirasakan anak yaitu dukungan emosional sebesar 63,04, dukungan instrumental sebesar 65,86, dan dukungan informasional sebesar 63,16 . Hasil ini menunjukkan bahwa ketiga dimensi dukungan sosial dirasakan cukup oleh anak baik dari orang tua, guru, dan teman.

Selanjutnya, rata-rata dukungan sosial pada anak laki-laki dan perempuan berturut-turut yaitu 64,96 dan 64,36 . Jika dilihat dari setiap dimensinya, rata-rata dukungan emosional pada laki-laki dan perempuan berturut-turut yaitu 62,96 dan 63,13; artinya persepsi anak dalam menerima dukungan emosional yang diberikan dari orang tua, guru, dan teman dirasakan cukup oleh anak, baik anak perempuan maupun anak laki-laki. Hasil yang sama ditunjukkan pada rata-rata dimensi dukungan instrumental dan dukungan informasional pada anak laki-laki dan perempuan, berturut-turut dukungan instrumental yaitu 65,69 dan 66,07 dan dukungan informasional yaitu 64,20 dan 61,89. 
Tabel 2 Nilai minimum, nilai maksimum, dan rata-rata dukungan sosial per dimensi (indeks)

\begin{tabular}{lcccccc}
\hline \multicolumn{1}{c}{ Variabel } & Min & $\begin{array}{l}\text { Laki-laki } \\
\text { Maks }\end{array}$ & Rataan \pm SD & Min & Maks & Rataan \pm SD \\
\hline $\begin{array}{l}\text { Dukungan } \\
\text { sosial }\end{array}$ & 27,00 & 92,00 & $64,96 \pm 14,31$ & 39,00 & 96,00 & $64,36 \pm 12,77$ \\
$\begin{array}{l}\text { Dukungan } \\
\text { emosional }\end{array}$ & 24,00 & 100,00 & $62,96 \pm 17,23$ & 36,00 & 93,00 & $63,13 \pm 13,53$ \\
$\begin{array}{l}\text { Dukungan } \\
\text { instrumental }\end{array}$ & 29,00 & 100,00 & $65,69 \pm 17,76$ & 37,00 & 100,00 & $66,07 \pm 14,76$ \\
$\begin{array}{l}\text { Dukungan } \\
\text { informasional }\end{array}$ & 10,00 & 96,00 & $64,20 \pm 15,69$ & 35,00 & 96,00 & $61,89 \pm 15,69$ \\
\hline
\end{tabular}

Rata-rata dukungan sosial berdasarkan jenis kelamin anak menunjukkan bahwa anak lakilaki lebih tinggi rata-rata pada dukungan informasional dan juga dukungan sosial secara keseluruhan. Sementara itu, anak perempuan mempunyai rata-rata dukungan emosional dan instrumental yang lebih tinggi dibandingkan anak laki-laki.

Selanjutnya, Tabel 3 menjelaskan rata-rata sumber dukungan sosial yang dirasakan anak menurut dimensi dukungan sosial. Penelitian ini menemukan bahwa rata-rata dukungan sosial dari orang tua pada anak laki-laki sebesar 73,71 dan rata-rata ini lebih rendah dari anak perempuan $(75,18)$. Temuan ini mengindikasikan bahwa anak perempuan lebih merasakan dukungan sosial dari orang tua, meskipun baik anak laki-laki maupun perempuan telah merasa cukup baik dengan dukungan orang tuanya. Hal-hal yang dilakukan orang tua sebagai bentuk dukungan sosialnya kepada anak antara lain benar-benar peduli dan sering memberi nasehat setiap hari kepada anak. Akan tetapi, saat ditanya tentang mencium anak dan memeluk anak, orang tua terlihat jarang dan hampir tidak pernah melakukan itu saat usia anak pada tingkat sekolah dasar. Jika dilihat dari dimensinya pada dukungan orang tua, hasil penelitian yang tersaji pada Tabel 3 menunjukkan bahwa anak laki-laki juga merasakan bahwa seluruh dimensi dukungan sosial lebih rendah dibandingkan anak perempuan.

Sementara itu, hasil yang sedikit berbeda ditunjukkan pada dukungan sosial yang berasal dari teman. Hasil yang tersaji pada Tabel 3 menunjukkan bahwa dukungan dari teman merupakan dukungan sosial yang paling rendah dirasakan anak dibandingkan dukungan dari orang tua dan guru, baik pada anak laki-laki maupun perempuan. Dilihat dari skor rata-rata yang masih di bawah 60,00; menunjukkan bahwa anak merasakan dukungan sosial yang rendah dari teman.

Tabel 3 Nilai minimum, nilai maksimum, dan rata-rata berdasarkan sumber dukungan sosial pada laki-laki dan perempuan

\begin{tabular}{|c|c|c|c|c|c|c|}
\hline \multirow{2}{*}{$\begin{array}{c}\text { Sumber dan dimensi } \\
\text { dukungan sosial }\end{array}$} & \multicolumn{3}{|c|}{ Laki-laki } & \multicolumn{3}{|c|}{ Perempuan } \\
\hline & Min & Maks & Rataan $\pm S D$ & Min & Maks & Rataan $\pm S D$ \\
\hline Orang tua & 36,00 & 100,00 & $73,71 \pm 14,44$ & 40,00 & 100,00 & $75,18 \pm 13,86$ \\
\hline $\begin{array}{l}\text { Dukungan } \\
\text { emosional }\end{array}$ & 25,00 & 100,00 & $73,04 \pm 18,98$ & 33,00 & 100,00 & $74,33 \pm 17,30$ \\
\hline $\begin{array}{l}\text { Dukungan } \\
\text { instrumental }\end{array}$ & 22,00 & 100,00 & $78,75 \pm 20,67$ & 44,00 & 100,00 & $81,84 \pm 19,53$ \\
\hline $\begin{array}{l}\text { Dukungan } \\
\text { informasional }\end{array}$ & 22,00 & 100,00 & $69,15 \pm 21,00$ & 11,00 & 100,00 & $69,31 \pm 21,38$ \\
\hline Teman & 0,00 & 91,00 & $57,49 v 18,06$ & 25,00 & 100,00 & $55,58 \pm 17,80$ \\
\hline $\begin{array}{l}\text { Dukungan } \\
\text { emosional }\end{array}$ & 0,00 & 100,00 & $50,65 \pm 23,93$ & 0,00 & 100,00 & $52,67 \pm 25,67$ \\
\hline $\begin{array}{l}\text { Dukungan } \\
\text { instrumental }\end{array}$ & 0,00 & 100,00 & $57,55 \pm 25,27$ & 0,00 & 100,00 & $50,38 \pm 23,29$ \\
\hline $\begin{array}{l}\text { Dukungan } \\
\text { informasional }\end{array}$ & 0,00 & 100,00 & $64,13 \pm 22,01$ & 22,00 & 100,00 & $61,69 \pm 20,39$ \\
\hline Guru & 16,00 & 100,00 & $62,62 \pm 19,72$ & 33,00 & 100,00 & $60,98 \pm 16,84$ \\
\hline $\begin{array}{l}\text { Dukungan } \\
\text { emosional }\end{array}$ & 0,00 & 100,00 & $62,87 \pm 23,05$ & 16,00 & 100,00 & $60,56 \pm 20,88$ \\
\hline $\begin{array}{l}\text { Dukungan } \\
\text { instrumental }\end{array}$ & 0,00 & 100,00 & $58,13 \pm 25,82$ & 11,00 & 100,00 & $60,78 \pm 23,67$ \\
\hline $\begin{array}{l}\text { Dukungan } \\
\text { informasional }\end{array}$ & 0,00 & 100,00 & $66,35 \pm 20,04$ & 33,00 & 100,00 & $61,16 \pm 18,04$ \\
\hline
\end{tabular}


Temuan ini mengindikasikan bahwa pada periode anak usia sekolah, dukungan sosial orang tua dan keluarga merupakan dukungan yang paling tinggi dirasakan dibandingkan dukungan dari teman. Hasil lain juga menemukan bahwa baik anak laki-laki maupun perempuan, merasa bahwa dukungan informasional dari teman mempunyai capaian tertinggi dibandingkan dukungan emosional dan instrumental dari teman. Selain itu, berdasarkan jenis kelamin anak, anak laki-laki mempunyai rata-rata dukungan sosial dari teman yang lebih tinggi dibandingkan anak perempuan.

Sama halnya dengan dukungan yang dirasakan anak dari guru, anak laki-laki mempunyai rata-rata dukungan dari guru yang lebih tinggi dibandingkan anak perempuan; yang mana rata-rata menunjukkan anak telah mempunyai dukungan sosial yang cukup baik dari guru. Meskipun rata-rata ini masih di bawah dukungan dari orang tua. Hasil lain yang tersaji pada Tabel 3 menunjukkan dukungan yang paling tinggi dirasakan anak dari guru adalah dukungan informasional, baik pada anak laki-laki maupun anak perempuan. Kondisi ini berbanding terbalik dengan dukungan dari orang tua yang dirasakan anak, yang mana anak merasa dukungan emosional orang tua lebih tinggi dibandingkan dukungan informasional. Dukungan emosional dari guru mempunyai rata-rata terendah pada anak lakilaki. Hasil uji beda tidak menunjukkan adanya perbedaan yang signifikan antara anak laki-laki dan perempuan, baik pada dukungan sosial secara keseluruhan ataupun dukungan sosial per dimensi.

\section{Kelekatan Emosi}

Hasil penelitian menunjukkan proporsi terbesar kategori kelekatan emosi yang diberikan ibu kepada anaknya berada pada kategori rendah yang ditunjukkan dari 48 persen anak yang mempunyai skor kelekatan emosi dengan ibu di bawah 60,00. Jika dilihat dari rata-rata, hasil penelitian ini menemukan bahwa rata-rata indeks kelekatan emosi yang dibangun antara anak dan ibu sebesar 61,80. Sementara itu, nilai terendah kelekatan emosi adalah sebesar 27,00 dan nilai tertinggi sebesar 100,00.

Sementara itu, rata-rata kelekatan emosi antara ibu dengan anak laki-laki adalah 61,98, sedikit lebih tinggi daripada anak perempuan yang hanya 61,58 . Nilai rata-rata tersebut menunjukkan bahwa rata-rata ibu dan anak usia sekolah di perdesaan, baik laki-laki maupun perempuan, mempunyai kelekatan emosi yang cukup bahkan mengarah ke kurang. Artinya anak terkadang merasa bahwa kelekatannya dengan ibu terkadang sudah cukup dan terkadang masih kurang. Sementara itu, berdasarkan jenis kelamin anak dan proporsi kelekatan ibu-anak berdasarkan kategori, hasil penelitian menemukan bahwa proporsi terbesar adalah anak laki-laki $(26,0 \%)$ dan anak perempuan (22,0\%) yang mempunyai kelekatan emosi rendah dengan ibunya. Hal ini juga ditegaskan dengan temuan bahwa proporsi terkecil adalah anak laki-laki $(10,0 \%)$ dan anak perempuan $(7,0 \%)$ yang mempunyai kelekatan emosi tinggi dengan ibunya.

\section{Prestasi Akademik}

Dalam penelitian ini, prestasi akademik anak dikategorikan ke dalam 4 kategori yaitu sangat baik $(3,50-4,00)$, baik $(3,00-3,49)$, cukup $(2,50$ $2,99)$, dan kurang $(0,00-2,49)$ sesuai dengan Permendikbud Nomor 81 A Tahun 2013. Ratarata nilai rapor diambil dari sembilan mata pelajaran yaitu Pendidikan Agama Islam, Pendidikan dan Kewarganegaraan, Bahasa Indonesia, Matematika, IImu Pengetahuan Alam, IImu Pengetahuan Sosial, Sosial Budaya dan Kesenian, Pendidikan Jasmani dan Kesehatan, serta Bahasa Sunda di Semester 1 Tahun Akademik 2015/2016. Rata-rata indeks prestasi akademik atau nilai anak pada penelitian ini yaitu 75,94 dengan nilai minimal 65,00 dan nilai maksimalnya 87,00. Adapun rata-rata prestasi akademik pada anak laki-laki sebesar 75,96, lebih tinggi sedikit dari rata-rata prestasi akademik anak perempuan yaitu 75,91 .

Apabila dianalisis lebih lanjut berdasarkan kategori prestasi akademik, pada penelitian ini menemukan proporsi terbesar nilai rapor anak hanya pada kategori cukup dan baik, yaitu berturut-turut 37,0 persen dan 63,0 persen. Berdasarkan jenis kelamin, prestasi akademik anak dengan kategori cukup pada laki-laki dan perempuan berturut-turut yaitu 21,0 persen dan 16,0 persen. Sementara itu, pada kategori baik nilai rapor anak laki-laki dan perempuan berturut-turut yaitu 34,0 persen dan 29,0 persen.

\section{Hubungan antara Karakteristik Anak, Keluarga, Sumber Dukungan Sosial, Kelekatan Emosi, dan Prestasi Akademik}

Hasil dari uji hubungan antara kelekatan emosi, dukungan sosial, dan prestasi akademik disajikan pada Tabel 4. Hasil penelitian menemukan bahwa uji hubungan antarvariabel penelitian menunjukkan adanya hubungan signifikan positif antara dukungan 
sosial secara keseluruhan dengan kelekatan emosi ibu-anak $(r=0,403 ; p<0,01)$. Artinya semakin tinggi dukungan sosial yang diterima anak dari orang tua, guru, dan teman maka kelekatan emosi ibu-anak akan semakin tinggi. Bahkan bila dilihat per dimensi dan sumber dukungan sosial, semua dimensi dan sumber dukungan sosial secara konsisten berhubungan nyata positif dengan kelekatan emosi ibu-anak. Hasil ini menegaskan bahwa dengan ditemukan masih rendahnya kelekatan emosi ibu-anak SD di perdesaan maka peran dukungan sosial akan dapat memberikan kontribusi terhadap peningkatan kelekatan emosi ibu-anak.

Adapun variabel lain yang memperlihatkan adanya hubungan positif signifikan yaitu hubungan antara kelekatan emosi dengan prestasi akademik ( $r=0,272 ; p<0,01)$. Artinya semakin baik kelekatan yang dibangun antara ibu dengan anak maka prestasi akademik anak akan semakin baik. Kelekatan emosi yang dibangun yaitu seperti anak selalu menceritakan kepada ibu segala hal pribadinya seperti perasaan, hubungan dengan teman, dan aktivitas atau kegiatan yang dilakukan di sekolah atau di masyarakat, anak merasa nyaman dengan ibu, dan anak mendapatkan kasih sayang dari orang tua terutama ibu.

Tabel 4 Koefisien uji hubungan antarvariabel penelitian

\begin{tabular}{|c|c|c|}
\hline Variabel & $\begin{array}{l}\text { Kelekatan } \\
\text { emosi ibu- } \\
\text { anak }\end{array}$ & $\begin{array}{l}\text { Prestasi } \\
\text { akademik }\end{array}$ \\
\hline $\begin{array}{l}\text { Dukungan emosional } \\
\text { orang tua }\end{array}$ & $0,216^{\star}$ & $-0,005$ \\
\hline $\begin{array}{l}\text { Dukungan } \\
\text { instrumental orang } \\
\text { tua }\end{array}$ & $0,233^{*}$ & $-0,023$ \\
\hline $\begin{array}{l}\text { Dukungan } \\
\text { informasional orang } \\
\text { tua }\end{array}$ & $0,386^{*}$ & $0,326^{* *}$ \\
\hline $\begin{array}{l}\text { Dukungan emosional } \\
\text { teman }\end{array}$ & $0,211^{*}$ & 0,089 \\
\hline $\begin{array}{l}\text { Dukungan } \\
\text { instrumental teman }\end{array}$ & $0,243^{*}$ & 0,112 \\
\hline $\begin{array}{l}\text { Dukungan } \\
\text { informasional teman }\end{array}$ & $0,289^{*}$ & $-0,025$ \\
\hline $\begin{array}{l}\text { Dukungan emosional } \\
\text { guru }\end{array}$ & $0,266^{*}$ & 0,029 \\
\hline $\begin{array}{l}\text { Dukungan } \\
\text { instrumental guru }\end{array}$ & $0,181^{*}$ & $-0,052$ \\
\hline $\begin{array}{l}\text { Dukungan } \\
\text { informasional guru }\end{array}$ & $0,283^{*}$ & 0,066 \\
\hline Dukungan sosial total & $0,403^{\star *}$ & 0,150 \\
\hline Kelekatan emosi & - & $0,272^{* *}$ \\
\hline
\end{tabular}

Selanjutnya, pada dimensi dukungan sosial terdapat hubungan signifikan positif antara dukungan informasional dari orang tua dengan prestasi akademik $(r=0,326 ; p<0,01)$ yang berarti semakin tinggi pemberian nasehat dan bimbingan dari orang tua kepada anak maka prestasi akademik anak akan semakin baik.

\section{Pengaruh Karakteristik anak, Karakteristik Keluarga, Kelekatan Emosi, Dukungan Sosial terhadap Prestasi Akademik}

Model regresi pada penelitian ini dikonstruksi untuk menguji pengaruh variabel bebas yang meliputi karakteristik anak antara lain jenis kelamin dan usia; karakteristik keluarga antara lain usia orang tua, pendidikan orang tua, pekerjaan orang tua, pendapatan per kapita keluarga, dan jumlah anggota keluarga; dukungan sosial (per dimensi dan sumber); dan kelekatan emosi-ibu anak terhadap prestasi akademik anak usia sekolah pada keluarga perdesaan. Model regresi memiliki nilai signifikansi 0,047 , yang artinya nilai signifikansi masih di bawah 0,05 yang menunjukkan model regresi memiliki pengaruh yang signifikan terhadap variabel terikat pada tingkat kepercayaan 95\%. Model regresi yang diperoleh memiliki nilai Adjusted $R$-Square sebesar 0,089 yang artinya hanya 8,9 persen varian prestasi akademik anak dapat dijelaskan oleh setiap perubahan dari variabel bebas dalam model regresi pada penelitian ini dan sisanya sebesar 91,1 persen prestasi akademik dipengaruhi oleh variabel bebas lain yang tidak diteliti dalam penelitian ini (Tabel 5).

Tabel 5 menunjukkan hanya variabel bebas dukungan informasional dari orang tua yang berpengaruh positif signifikan terhadap prestasi akademik $(B=0,059)$. Artinya setiap satu indeks kenaikan dukungan informasional orang tua akan meningkatkan skor prestasi akademik sebesar 0.059 poin. Variabel independen lain seperti karakteristik anak yang meliputi usia dan jenis kelamin; karakteristik keluarga yang meliputi usia ibu, lama pendidikan ayah, lama pendidikan ibu, pendapatan per kapita, dan jumlah anggota keluarga; serta kelekatan emosi menunjukkan tidak berpengaruh signifikan terhadap prestasi akademik. Selain itu, variabel dukungan orangtua (dukungan emosional dan istrumental), dukungan teman (dukungan emosional, informasional, dan instrumental) dan dukungan guru (dukungan emosional, informasional, dan instrumental) juga tidak berpengaruh signifikan terhadap prestasi akademik. 
Tabel 5 Analisis regresi linier berganda pada karakteristik anak, karakteristik keluarga, kelekatan emosi, dan dukungan sosial terhadap prestasi akademik

\begin{tabular}{|c|c|c|c|c|}
\hline \multirow[t]{2}{*}{ Variabel Bebas } & \multicolumn{2}{|c|}{$\begin{array}{l}\text { Koefisien Tidak } \\
\text { Terstandarisasi }\end{array}$} & $\begin{array}{c}\text { Koefisien } \\
\text { Terstandarisasi }\end{array}$ & \multirow[t]{2}{*}{ Sig. } \\
\hline & B & Std. Error & $\beta$ & \\
\hline Konstanta & 80,673 & 7,291 & 11,065 & 0,000 \\
\hline Usia anak (tahun) & $-0,380$ & 0,541 & $-0,075$ & 0,484 \\
\hline Jenis kelamin (1=laki-laki,2=perempuan) & $-0,329$ & 0,906 & $-0,363$ & 0,717 \\
\hline Usia ibu (tahun) & $-0,015$ & 0,055 & $-0,030$ & 0,782 \\
\hline Lama pendidikan ayah (tahun) & 0,210 & 0,180 & 0,133 & 0,247 \\
\hline Lama pendidikan ibu (tahun) & $-0,383$ & 0,217 & $-0,200$ & 0,082 \\
\hline Pendapatan per kapita (Rp/kapita/bulan) & $-7,032 \mathrm{E}^{8}$ & 0,000 & $-0,008$ & 0,940 \\
\hline Jumlah anggota keluarga (orang) & $-0,437$ & 0,311 & $-0,146$ & 0,163 \\
\hline Kelekatan emosi (skor) & 0,047 & 0,026 & 0,209 & 0,068 \\
\hline Dukungan emosional orang tua (skor) & $-0,026$ & 0,028 & $-0,112$ & 0,351 \\
\hline Dukungan instrumental orang tua (skor) & $-0,003$ & 0,025 & $-0,014$ & 0,904 \\
\hline Dukungan informasional orang tua (skor) & 0,059 & 0,024 & 0,296 & $0,015^{\star \star}$ \\
\hline Dukungan emosional teman (skor) & 0,017 & 0,021 & 0,098 & 0,426 \\
\hline Dukungan instrumental teman (skor) & 0,010 & 0,020 & 0,060 & 0,606 \\
\hline Dukungan informasional teman (skor) & $-0,027$ & 0,026 & $-0,135$ & 0,307 \\
\hline Dukungan emosional guru (skor) & 0,001 & 0,027 & 0,003 & 0,984 \\
\hline Dukungan instrumental guru (skor) & $-0,013$ & 0,023 & $-0,078$ & 0,566 \\
\hline Dukungan informasional guru (skor) & $-0,009$ & 0,033 & $-0,039$ & 0,797 \\
\hline $\mathrm{F}$ & & & & \\
\hline Sig. & & & & \\
\hline $\mathrm{R}^{2}$ & & & & \\
\hline Adjusted $R$ Square & & & & \\
\hline
\end{tabular}

\section{PEMBAHASAN}

Penelitian ini menemukan bahwa karakteristik anak dan karakteristik keluarga tidak memiliki pengaruh yang signifikan terhadap prestasi akademik secara langsung meskipun model regresi yang diuji telah signifikan. Hal ini berbeda dengan penelitian Saleh (2014) yang menyatakan faktor orang tua sangat berpengaruh terhadap keberhasilan anak dalam belajar, pendidikan orang tua, besar kecilnya penghasilan, dan usia orang tua dalam pencapaian hasil belajar anak. Akan tetapi, hasil penelitian ini sejalan dengan Sunarti et al. (2005) yang menyatakan perekonomian keluarga tidak berpengaruh secara langsung terhadap prestasi belajar anak, melainkan melalui kualitas perkawinan dan pengasuhan anak. Hasil temuan dari penelitian ini menemukan bahwa kondisi sosial ekonomi keluarga perdesaan tidak memberikan pengaruh secara langsung terhadap prestasi akademik anak usia sekolah.

Model regresi juga tidak menemukan pengaruh langsung kelekatan emosi ibu-anak terhadap prestasi akademik anak, meskipun model regresi signifikan. Kelekatan emosi ibu-anak hanya ditemukan hubungan secara signifikan pada uji korelasi dengan prestasi akademik anak. Hal ini tidak sejalan dengan penelitian Shmueli-Goetz et al. (2008) yang menemukan bahwa kelekatan yang dibangun antara orang tua dan anak dapat dilihat dari bukti nonverbal respon emosional dan kognitif anak. Temuan tersebut mengindikasikan bahwa kelekatan emosi berpengaruh terhadap prestasi akademik, melalui pengembangan self-efficacy anak dan peran orang tua dalam memberi kasih sayang, perhatian, dan pengasuhan. Hal ini akan mendorong anak untuk mengeksplorasi lingkungannya sehingga anak memiliki self-efficacy dan motivasi yang baik dan merasa percaya diri dalam mencapai prestasi akademiknya (Chen, 2015). Jika dilihat pada karakteristik keluarga perdesaan, temuan penelitian ini kemungkinan berkaitan dengan kondisi orang tua yang jarang membangun tipe-tipe interaksi yang dapat menumbuhkan kelekatan orang tua dengan anak yang sudah semakin bertambah usianya. Hal ini terlihat ketika melakukan wawancara, hampir tidak pernah ataupun jarang sekali ditemukan ibu yang mencium dan memeluk anak ketika anak sedih dan memiliki masalah dengan temannya.

Namun, hasil penelitian ini menemukan adanya pengaruh nyata dan positif variabel dukungan informasional dari orang tua terhadap prestasi akademik anak. Hasil uji regresi ini ditemukan konsisten dengan hasil uji korelasi. Temuan ini mengindikasikan bahwa dukungan orang tua dalam memberikan 
saran, nasehat, motivasi, dan membantu anak ketika memiliki masalah sangat berperan terhadap prestasi akademik anak. Pada keluarga perdesaan, dukungan informasional orang tua bermakna besar terhadap prestasi akademik anak khususnya anak usia sekolah. Hasil penelitian tersebut sejalan dengan penelitian Gordon (2011) yang menyatakan dukungan sosial orang tua yang diberikan kepada anak akan memberikan kenyamanan pada diri anak. Anak akan mampu mengendalikan emosi dan anak memiliki kemampuan adaptif yang tinggi. Ketika anak mengeksplorasi lingkungannya, anak dituntut untuk mampu menyesuaikan dengan kondisi di sekitarnya. Seseorang membutuhkan dukungan sosial untuk menghadapi situasi yang penuh tekanan, yang mana pada anak usia sekolah dapat diperoleh dari keluarga, guru, dan teman (Richey et al., 1996). Hasil penelitian lain menegaskan pada usia remaja dukungan sosial yang diterima akan memberi pengaruh pada self regulation dan self efficacy anak dalam mencapai kepuasan sekolah (Sivandani et al., 2013) yang akan memicu anak mencapai prestasi akademik yang lebih baik. Dukungan sosial memiliki pengaruh tidak langsung terhadap strategi pengaturan diri, melalui strategi pengaturan diri inilah anak mampu mencapai prestasi akademik yang baik (Situmorang \& Latifah, 2014). Keluarga perdesaan dalam penelitian ini memiliki rasa peduli yang cukup kepada anak, terlihat saat melakukan wawancara di dalam kuesioner yang menyatakan orang tua benar-benar peduli ketika anak memiliki kebutuhan yang belum terpenuhi. Temuan pada penelitian ini menegaskan peran yang cukup besar dari dukungan sosial orang tua, khususnya yang berbentuk penyediaan informasi dari orang tua; terhadap pencapaian prestasi akademik anak.

Pada keluarga perdesaan terlihat bahwa dukungan informasional yang diberikan anak masih tergolong rendah. Artinya, meskipun dukungan informasional yang diberikan orang tua masih rendah, akan tetapi dukungan ini memiliki hubungan yang bermakna besar dengan pencapaian prestasi akademik anak. Hubungan antara dukungan informasional orang tua dengan prestasi akademik ini sejalan dengan penelitian Khan et al. (2014) yang menyatakan dukungan orang tua yang diberikan kepada anak akan memengaruhi motivasi anak untuk meningkatkan prestasinya dan melanjutkan pendidikan. Dukungan ini berperan penting sebagai faktor protektif yaitu faktor yang melindungi, meringankan, menyangga, dan dengan demikian mengurangi resiko yang dialami individu sehingga individu terbantu melakukan penyesuaian sosial yang adaptif. Pada usia lebih tinggi yaitu pada remaja, sejalan dengan penelitian Cutrona et al. (1994), ditemukan bahwa dukungan sosial orang tua yang diberikan kepada anak dewasa secara signifikan meningkatkan indeks prestasi kumulatifnya.

Meskipun uji model regresi tidak menemukan adanya pengaruh langsung kelekatan emosi ibu-anak terhadap prestasi akademik, namun hasil uji hubungan menemukan hubungan positif signifikan antara kelekatan emosi dengan prestasi akademik. Kelekatan yang dibangun antara ibu dengan anak akan berhubungan dengan pencapaian prestasi anak. Hasil penelitian ini sejalan dengan Maltais et al. (2015) yang menemukan kelekatan emosi merupakan variabel yang berhubungan nyata dengan kompetensi prestasi akademik anak, orang tua yang memberi keamanan, kasih sayang, dan rasa hormat, serta melihat anak sebagai individu yang dapat dipercaya dan responsif dengan kondisi anak. Hal ini akan mendorong rasa ingin tahu anak, anak akan berusaha mengeksplorasi keterampilan kognitifnya, dan anak memiliki kemampuan memecahkan masalah. Hasil penelitian Miller \& Commons (2010) menyatakan pengasuhan dengan praktek kelekatan pada anak akan mengurangi stres pada anak dan anak memiliki perkembangan fisik, psikologis, dan kognitif yang baik karena anak mampu mengatur emosinya, serta membuat anak nyaman dalam mencapai pencapaian prestasinya. Oleh karenanya, penelitian yang dilakukan pada keluarga perdesaan ini menegaskan kembali pentingnya kelekatan emosi antara ibu dan anak dalam mencapai prestasi akademik anak yang baik. Artinya kelekatan emosi ini berpengaruh terhadap prestasi akademik melalui perkembangan self-efficacy anak (Chen, 2015).

Temuan bahwa kelekatan emosi ibu-anak hanya mempunyai hubungan yang nyata sedangkan dukungan informasional orang tua mempunyai hubungan sekaligus pengaruh langsung yang nyata terhadap prestasi akademik; mengindikasikan kemungkinan peran tidak langsung kelekatan emosi ibu-anak terhadap peningkatan prestasi akademik melalui dukungan informasional orang tua. Hal ini terlihat dari hasil uji korelasi dalam penelitian ini yang mana dukungan sosial yang diterima anak (termasuk di dalamnya dukungan informasional orang tua) berhubungan positif nyata dengan kelekatan 
emosi ibu-anak. Kelekatan yang dibangun seperti hubungan kedekatan antara ibu dan anak, anak bercerita tentang perasaannya kepada ibu, anak merasa nyaman dengan ibu, dan kepedulian ibu terhadap kondisi anak. Sama halnya ketika dukungan sosial yang diberikan kepada anak seperti pemberian kasih sayang; pemberian materi atau uang; dan nasehat atau saran. Hubungan antara kelekatan emosi dengan dukungan sosial ini sejalan dengan penelitian Cutrona et al. (1994) yang menunjukkan adanya hubungan antara kelekatan emosi yang dibangun antara orang tua seperti memberi bimbingan, saran, menghormati pendapat anak, dan membangun kepentingan bersama; sama halnya ketika orang tua memberi pengasuhan dan dukungan sosial kepada anak. Hasil penelitian lain, Pangestuti \& Widayat (2013) juga menyatakan adanya hubungan signifikan antara dukungan sosial dengan maternal affectionate attachment pada anak. Oleh karenanya, kajian-kajian lebih lanjut untuk menelaah peran kelekatan emosi ibu-anak terhadap prestasi akademik melalui berbagai macam variabel lain perlu dilakukan. Begitu pula penyempurnaan instrumen kelekatan emosi pada penelitian-penelitian selanjutnya perlu dilakukan sehingga ditemukan instrumen kelekatan emosi yang reliabel dan valid untuk digunakan untuk masyarakat Indonesia, khususnya di perdesaan.

Penelitian ini mempunyai keterbatasan bahwasanya kelekatan emosi dan dukungan sosial hanya diukur dengan melakukan wawancara dan tidak melakukan ke tahap pengamatan karena faktor keterbatasan sumber daya waktu. Penelitian ini juga hanya melihat prestasi akademik dari nilai rapor, yang merupakan nilai berdasarkan standar yang ditetapkan di sekolah sehingga nilai yang didapat tidak bervariasi. Selain itu, penelitian ini hanya melihat pengaruh prestasi akademik dari faktor eksternal dan tidak melihat atau meneliti dari faktor internal anak.

\section{SIMPULAN DAN SARAN}

Hasil penelitian menjelaskan kelekatan emosi yang dirasakan anak usia sekolah di perdesaan berada pada kategori rendah, akan tetapi persepsi anak terhadap dukungan sosial yang diterimanya dalam kategori sedang, dan prestasi akademik anak berada pada kategori baik. Namun, tidak ada perbedaan antara lakilaki dan perempuan dalam rata-rata kelekatan emosi dan dukungan sosial yang dirasakan anak, keduanya dalam kategori sedang. Artinya kelekatan emosi dan dukungan sosial yang diberikan anak dirasa cukup. Hasil penelitian ini menyatakan semakin baik kelekatan emosi yang dibangun maka semakin baik dukungan sosial yang diterima oleh anak. Hasil juga menemukan bahwa ibu di perdesaan yang membangun kelekatan emosi yang baik maka berhubungan nyata dengan prestasi akademik anak yang semakin baik. Selain itu, orang tua di perdesaan yang memberi dukungan informasional yang baik maka berhubungan nyata dengan prestasi akademik anak yang semakin baik. Peningkatan dukungan informasional orang tua juga ditemukan secara konsisten berpengaruh nyata terhadap peningkatan pencapaian prestasi akademik anak usia sekolah di perdesaan. Artinya dukungan informasional seperti memberi nasehat dan motivasi dari orang tua yang diberikan kepada anak akan memengaruhi secara langsung peningkatan prestasi akademik anak pada keluarga perdesaan.

Hasil penelitian menunjukkan pengaruh positif dari dukungan informasional orang tua terhadap prestasi akademik dan adanya hubungan antara kelekatan emosi dengan dukungan sosial yang diberikan kepada anak. Oleh karena itu, disarankan kepada pihak orang tua untuk meningkatkan komunikasi dan perhatian kepada anak. Rata-rata kelekatan emosi ibu-anak dan dukungan sosial yang dirasa anak (baik dari orang tua, guru, dan teman) dalam penelitian ini ditemukan masih belum dalam kategori baik. Oleh sebab itu, peranan orang tua maupun guru sangatlah penting untuk memperhatikan apa yang menjadi kebutuhan anak pada usia seperti ini sehingga anak mampu mencapai prestasi akademik yang baik. Selain itu, berdasarkan keterbatasan penelitian, penelitian ini menyarankan bahwa kajian serupa perlu dilakukan dalam cakupan usia responden yang lebih beragam dan penambahan variabel independen lain untuk lebih menjelaskan peran kelekatan emosi ibu-anak terhadap prestasi akademik anak.

\section{DAFTAR PUSTAKA}

Akbar, R. \& Hawadi. (2001). Psikologi perkembangan anak mengenal sifat, bakat, dan kemampuan anak. Jakarta, ID: Grasindo.

Cutrona, C. E., Cole, V., Colangelo, N., Assouline, S. G., \& Russell, D. W. (1994). Perceived parental social support and academic achievement: An attachment theory. Journal of Personality and Social Psychology, 2, 369- 378. 
Chen, W. W. (2015). The relations between perceived parenting styles and academic achievement in Hongkong: The maediating role of students goal orientations. Learning and Individual Differences, 37, 48-54.

Gordon, A. T. (2011). Assessing social support in children: development and initial validation of the social support questionnaire for children (Disertasi). Louisiana State University, Louisiana, Amerika Serikat.

Khan, A., Ahmad, R., Hamdan, A. R., Mustaffa, M. S. (2014). Educational encouragement, parenting styles, gender and ethnicity as predictors of academic achievement among sprecial education students. International Education Studies, 7, 18-24.

Khomsan, A. (2000). Teknik pengukuran pengetahuan gizi. Bogor: Jurusan Gizi Masyarakat dan Sumber Daya Keluarga Fakultas Pertanian Institut Pertanian Bogor.

Lamont, M. (2010). Mother-child attachment and preschool behaviour problems in children with developmental delays (Disertasi). Utah State University, Utah, Amerika Serikat.

Lau, S. R., Beilby, J. M., Byrnes, M. L., \& Hennessey, N. W. (2012). Parenting styles and attachment in school-aged children who stutter. Journal of communication disorders, 45, 98-110.

Maltais, C., Duchesne, S., Ratelle, C. F., Feng, B. (2015). Attachment to the mother and achievement goal orientations at the beginning of middle school: The mediating roleh of academic competence and anxiety. Learning and Individual Differences, 39, 39-48.

Miller, P. M. \& Commons, M. L. (2010). The benefits of attachment parenting for infants and children: Behavioral developmental view. Behavioral Developmental Bulletin, 1, 1-14.

Pangestuti, I. M., Widayat, I. W. (2013). Hubungan dukungan sosial dengan maternal affectionate attachment antara ibu dan balita pada ibu pekerja sektor formal. Jurnal Psikologi Pendidikan dan Perkembangan, 2, 81-87.

Puspitawati, H. (2012). Gender dan keluarga: Konsep dan realita di Indonesia. Bogor, Indonesia: IPB Press.
Richey, C. A., Hodges, V. G., Siewert, P. A., Petitt, K. (1996). Social support characteristics among nonclinical African-American and Filipino-American parents with school-age children. Children and Youth Services Review, 18, 659-692.

Saleh, M. (2014). Pengaruh motivasi, faktor keluarga, lingkungan kampus dan aktif berorganisasi terhadap prestasi akademik. Jurnal Phenomenon, 4, 109141.

Santrock, J. W. (2007). Perkembangan anak edisi kesebelas jilid 1. Rachmawati M., Kuswanti A., penerjemah; Hardani W., editor. Child Development, Elevent Edition. Jakarta, Indonesia: Erlangga.

Shmueli-Goetz, Y., Target, M., Fonagy, P., Datta, A. (2008). The child attachment interview: A psychometric study of reliability and discriminant validity. Developmental Psychology, 44, 939956.

Situmorang, Z. R. D., Latifah, M. (2014). Pengaruh dukungan sosial, konsep diri, dan strategi pengaturan diri dalam belajar terhadap prestasi akademik. Jurnal IImu Keluarga dan Konsumen, 7(3), 154-163.

Sivandani, A., Koohbanani, S. E., Vahidi, T. (2013). The relationships between social support and self efficacy with academic achievement and school satisfaction among female junior high school students in Birjand. Procedia-Social and Behavioral Sciences, 84, 668-673.

Sunarti, E., Tati., Atat, S. N., Noorhaisma, R., Lembayung, D. P. (2005). Pengaruh tekanan ekonomi keluarga, dukungan sosial, kualitas perkawinan, pengasuhan, dan kecerdasan emosi anak terhadap prestasi belajar anak. Media Gizi \& Keluarga, 29, 34-40.

Surung, Y. \& Dahlan. (2012). Petani padi sawah dan kemiskinan (study kasus di Desa Pallantikang, Kecamatan Pattalassang, Kabupaten Gowa). Jurnal Agrisistem, 8, 43-59.

Tiwari, V., Tiwari, P. S. N., \& Sharma, K. (2014). Academic motivation and school performance among students. Indian Journal of Health and Wellbeing, 5, 437441.

Wandansari, Y. (2004). Peran dukungan orang tua dan guru terhadap penyesuaian 
sosial anak berbakat intelektual. Jurnal Provitae, 1, 29-42.

Yaacob, S. N., Idris, F. A., \& Wan, G. S. (2015). Parental attachment, coping efficacy and antisocial behavior among adolescents from divorced family in selangor, Malaysia. Journal of Management Reseacrh, 7(2), 364-374. 